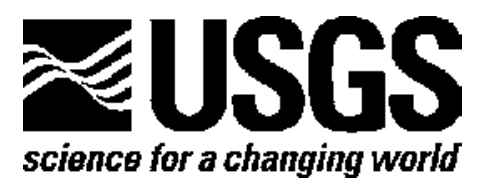

\title{
Effects of Catastrophic Floods and Debris Flows on the Sediment Retention Structure, North Fork Toutle River, Washington
}

By Roger P. Denlinger

Open-File Report 2011-1317

U.S. Department of the Interior U.S. Geological Survey 


\section{U.S. Department of the Interior \\ KEN SALAZAR, Secretary}

\section{U.S. Geological Survey \\ Marcia K. McNutt, Director}

U.S. Geological Survey, Reston, Virginia: 2012

For more information on the USGS-the Federal source for science about the Earth, its natural and living resources, natural hazards, and the environment, visit http://www.usgs.gov or call 1-888-ASK-USGS.

For an overview of USGS information products, including maps, imagery, and publications, visit http://www.usgs.gov/pubprod

Suggested citation:

Denlinger, R.P., 2012, Effects of catastrophic floods and debris flows on the sediment retention structure, North Fork Toutle River, Washington: U.S. Geological Survey Open-File Report 2011-1317, $25 \mathrm{p}$.

Any use of trade, product, or firm names is for descriptive purposes only and does not imply endorsement by the U.S. Government.

Although this report is in the public domain, permission must be secured from the individual copyright owners to reproduce any copyrighted material contained within this report. 


\section{Contents}

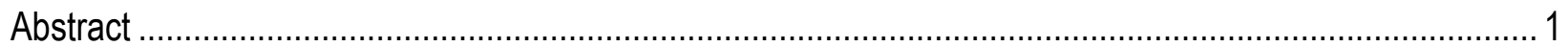

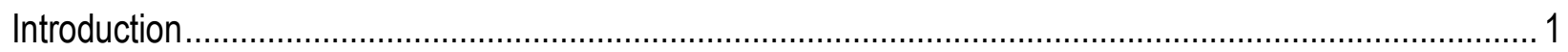

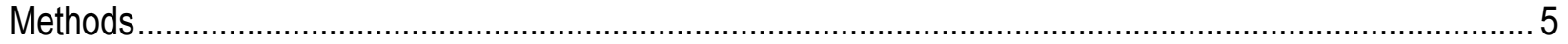

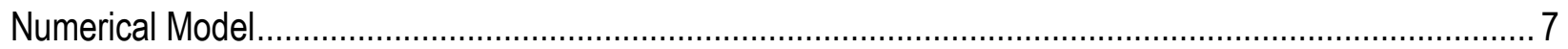

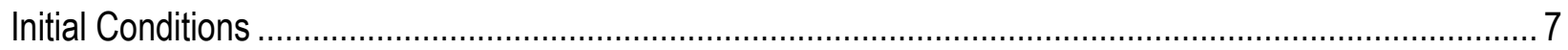

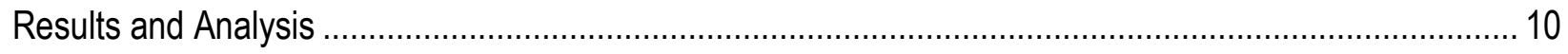

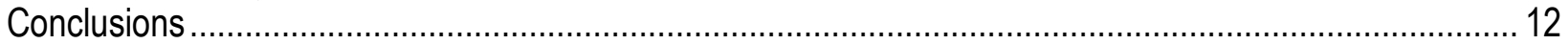

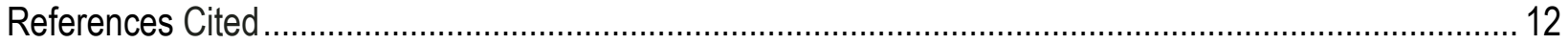

\section{Figures}

1. Photograph of Mount. St. Helens and Castle Lake upstream of the Sediment Retention Structure on the North Fork Toutle River, Washington ................................................................................ 4

2A. Shaded relief map of numerical domain used for flow simulations .................................................... 4

2B. Close-up image of Sediment Retention Structure (SRS) as it is discretized in the numerical domain, with the elevation of each point shown with flooded contours ...................................................... 5

3. Initial condition for Castle Lake and blockage.............................................................................

4. Initial conditions assumed for a debris flow from the crater of Mount St. Helens .................................. 10

5. Initial flooding conditions associated with breaching of the blockage forming Castle Lake and spillway

6. Initial flooding conditions associated with breaching of the blockage forming Castle Lake and spillway

7. Water depth at peak stage at the dam, as steady flow is achieved through the Sediment Retention Structure

8. Peak water surface elevation (stage), as steady flow is achieved through the Sediment Retention Structure for a partial dambreak flood from Castle Lake and a total flow volume of $29 \mathrm{Mm}^{3}$............... 17

9. Water depth at peak stage at the dam, as steady flow is achieved through the Sediment Retention Structure for a dambreak flood from complete failure of the blockage of Castle Lake ......................... 18

10. Peak water surface elevation (stage), as steady flow is achieved through the Sediment Retention Structure for a full dambreak flood from Castle Lake and a total flow volume of $56 \mathrm{Mm}^{3}$.

11. Hydrographs for both partial and complete failure of the blockage of Castle Lake, producing a dambreak flood that impacts the Sediment Retention Structure

12. Initial conditions for a debris flow formed from the blockage and lake volume, where outlet is blocked and lake volume is assumed to be fluidized debris to a depth of 41 meters, giving a total volume of $56 \mathrm{Mm}^{3}$

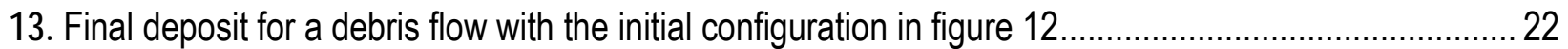

$14 \mathrm{~A}$. Snapshot of flow depths of hypothetical crater debris flow 1,500 seconds after release.................... 23

14 B. Snapshot of flow depth of hypothetical crater debris flow 1,500 seconds after release .................... 24

15. Deposit created by a debris flow originating in the crater of Mount St. Helens nearly 3 hours after release.

\section{Tables}

1. Material Properties and Dimensionless Parameters for Model Debris Flow Predictions......................... 7

2. Stage at Sediment Retention Structure for Different Dambreak Volumes. 


\section{Conversion Factors and Datum}

Conversion Factors

SI to Inch/Pound

\begin{tabular}{|c|c|c|}
\hline Multiply & By & To obtain \\
\hline \multicolumn{3}{|c|}{ Length } \\
\hline meter (m) & 3.281 & foot $(\mathrm{ft})$ \\
\hline meter (m) & 1.094 & yard (yd) \\
\hline \multicolumn{3}{|c|}{ Area } \\
\hline square meter $\left(\mathrm{m}^{2}\right)$ & 0.0002471 & acre \\
\hline square meter $\left(\mathrm{m}^{2}\right)$ & 10.76 & square foot $\left(\mathrm{ft}^{2}\right)$ \\
\hline \multicolumn{3}{|c|}{ Volume } \\
\hline cubic meter $\left(\mathrm{m}^{3}\right)$ & 6.290 & barrel (petroleum, 1 barrel = 42 gal) \\
\hline cubic meter $\left(\mathrm{m}^{3}\right)$ & 264.2 & gallon (gal) \\
\hline cubic meter $\left(\mathrm{m}^{3}\right)$ & 0.0002642 & million gallons (Mgal) \\
\hline million cubic meters $\left(\mathrm{Mm}^{3}\right)$ & 0.8107 & thousand acre-feet (taf) \\
\hline cubic meter $\left(\mathrm{m}^{3}\right)$ & 35.31 & cubic foot $\left(\mathrm{ft}^{3}\right)$ \\
\hline cubic meter $\left(\mathrm{m}^{3}\right)$ & 1.308 & cubic yard $\left(\mathrm{yd}^{3}\right)$ \\
\hline cubic meter $\left(\mathrm{m}^{3}\right)$ & 0.0008107 & acre-foot (acre-ft) \\
\hline \multicolumn{3}{|c|}{ Density } \\
\hline kilogram per cubic meter $\left(\mathrm{kg} / \mathrm{m}^{3}\right)$ & 0.06242 & pound per cubic foot $\left(\mathrm{lb} / \mathrm{ft}^{3}\right)$ \\
\hline \multicolumn{3}{|c|}{ Viscosity } \\
\hline square meters $/ \mathrm{sec}\left(\mathrm{m}^{2} / \mathrm{s}\right)$ & 10.8 & square foot per second $\left(\mathrm{ft}^{2} / \mathrm{s}\right)$ \\
\hline \multicolumn{3}{|c|}{ Flow rate } \\
\hline cubic meter per second $\left(\mathrm{m}^{3} / \mathrm{s}\right)$ & 70.07 & acre-foot per day (acre-ft/d) \\
\hline cubic meter per second $\left(\mathrm{m}^{3} / \mathrm{s}\right)$ & 35.31 & cubic foot per second $\left(\mathrm{ft}^{3} / \mathrm{s}\right)$ \\
\hline
\end{tabular}

Temperature in degrees Celsius $\left({ }^{\circ} \mathrm{C}\right)$ may be converted to degrees Fahrenheit $\left({ }^{\circ} \mathrm{F}\right)$ as follows: ${ }^{\circ} \mathrm{F}=\left(1.8 x^{\circ} \mathrm{C}\right)+32$.

Temperature in degrees Fahrenheit $\left({ }^{\circ} \mathrm{F}\right)$ may be converted to degrees Celsius $\left({ }^{\circ} \mathrm{C}\right)$ as follows: ${ }^{\circ} \mathrm{C}=\left({ }^{\circ} \mathrm{F}-32\right) / 1.8$.

\section{Datum}

Horizontal coordinate information is referenced to the North American Datum of 1983 (NAD 83). Elevation as used in this report, refers to distance above the vertical datum. 


\title{
Effects of Catastrophic Floods and Debris Flows on the Sediment Retention Structure, North Fork Toutle River, Washington
}

\author{
By Roger P. Denlinger
}

\begin{abstract}
The eruption of Mount St. Helens in 1980 produced a debris avalanche that flowed down the upper reaches of the North Fork Toutle River in southwestern Washington, clogging this drainage with sediment. In response to continuous anomalously high sediment flux into the Toutle and Cowlitz Rivers resulting from this avalanche and associated debris flows, the U.S. Army Corps of Engineers completed a Sediment Retention Structure (SRS) on the North Fork Toutle River in May 1989. For one decade, the SRS effectively blocked most of the sediment transport down the Toutle River. In 1999, the sediment level behind the SRS reached the elevation of the spillway base. Since then, a higher percentage of sediment has been passing the SRS and increasing the flood risk in the Cowlitz River.

Currently (2012), the dam is filling with sediment at a rate that cannot be sustained for its original design life, and the U.S. Army Corps of Engineers is concerned with the current ability of the SRS to manage floods. This report presents an assessment of the ability of the dam to pass large flows from three types of scenarios (it is assumed that no damage to the spillway will occur). These scenarios are (1) a failure of the debris-avalanche blockage forming Castle Lake that produces a dambreak flood, (2) a debris flow from failure of that blockage, or (3) a debris flow originating in the crater of Mount St. Helens. In each case, the flows are routed down the Toutle River and through the SRS using numerical models on a gridded domain produced from a digital elevation model constructed with existing topography and dam infrastructure. The results of these simulations show that a structurally sound spillway is capable of passing large floods without risk of overtopping the crest of the dam. In addition, large debris flows originating from Castle Lake or the crater of Mount St. Helens never reach the SRS. Instead, debris flows fill the braided channels upstream of the dam and reduce its storage capacity.
\end{abstract}

\section{Introduction}

The Sediment Retention Structure (SRS) on the North Fork Toutle River was completed in 1989 by the U.S. Army Corps of Engineers (Willingham, 2005). The purpose of the SRS is to block downstream transport of the deposits and sediment left by the catastrophic eruptions of Mount St. Helens in the summer of 1980, thereby reducing flood risk created by sediment deposition in the Cowlitz River. A photograph of the drainage basin upstream of the SRS is shown in figure 1, and a map of the SRS and its drainage basin are shown in figure 2a. The SRS 
is $56 \mathrm{~m}$ high and $575.5 \mathrm{~m}$ wide, with a crest elevation of $304.8 \mathrm{~m}$ and an original capacity of 197.3 million $\mathrm{m}^{3}$, and was designed to contain sediment until the year 2035. Since construction of the SRS, however, higher than anticipated sediment flux into SRS by occasional debris flows from the crater of Mount St. Helens as well as by common bank failures into the North Fork Toutle River during large storms (Major and Mark, 2006) has reduced the capacity of the SRS such that it is nearly full and passing substantial sediment (U.S. Geological Survey, 2012).

In addition to chronic sedimentation, potential catastrophic events could radically shorten the useful life of the SRS by causing rapid filling the valley behind the SRS dam with sediment. One such event could be a failure of the blockage forming Castle Lake, which was impounded when a southern tributary of the North Fork Toutle River was blocked by the debris avalanche on May 18, 1980 (Glicken, 1998, figs. 1 and 2). The lake presently has a volume of about 23 million $\mathrm{m}^{3}$. The U.S. Army Corps of Engineers constructed a spillway across this blockage in 1981 to stabilize the maximum lake level and prevent overtopping of the blockage. However, seepage failure of the blockage still poses flooding and debris flow hazards to the SRS (Roeloffs, 1994). Another plausible cause of rapid sediment accumulation behind the SRS is a debris flow from the crater of Mount St. Helens (Wolfe and Pierson, 1995).

To evaluate the likely outcomes from these events, numerical simulations were conducted to model large dambreak floods and large debris flows flowing into the drainage of the upper North Fork Toutle River and towards the SRS. The initial condition for the simulations consisted of specifying source conditions at Castle Lake and in the crater of Mount St. Helens, and specifying flow composition on the basis of local geologic and geomorphic conditions.

Numerical flow modeling allowed computation of flow and deposition conditions for the three dimensional terrain down to and through the SRS. These calculations rely on algorithms developed either for dambreak floods (Denlinger and O’Connell, 2008) or for debris flows (Denlinger and Iverson, 2001) depending on whether the source volume consists of water or saturated debris. No assessment of structural integrity of the SRS is made in this work. 


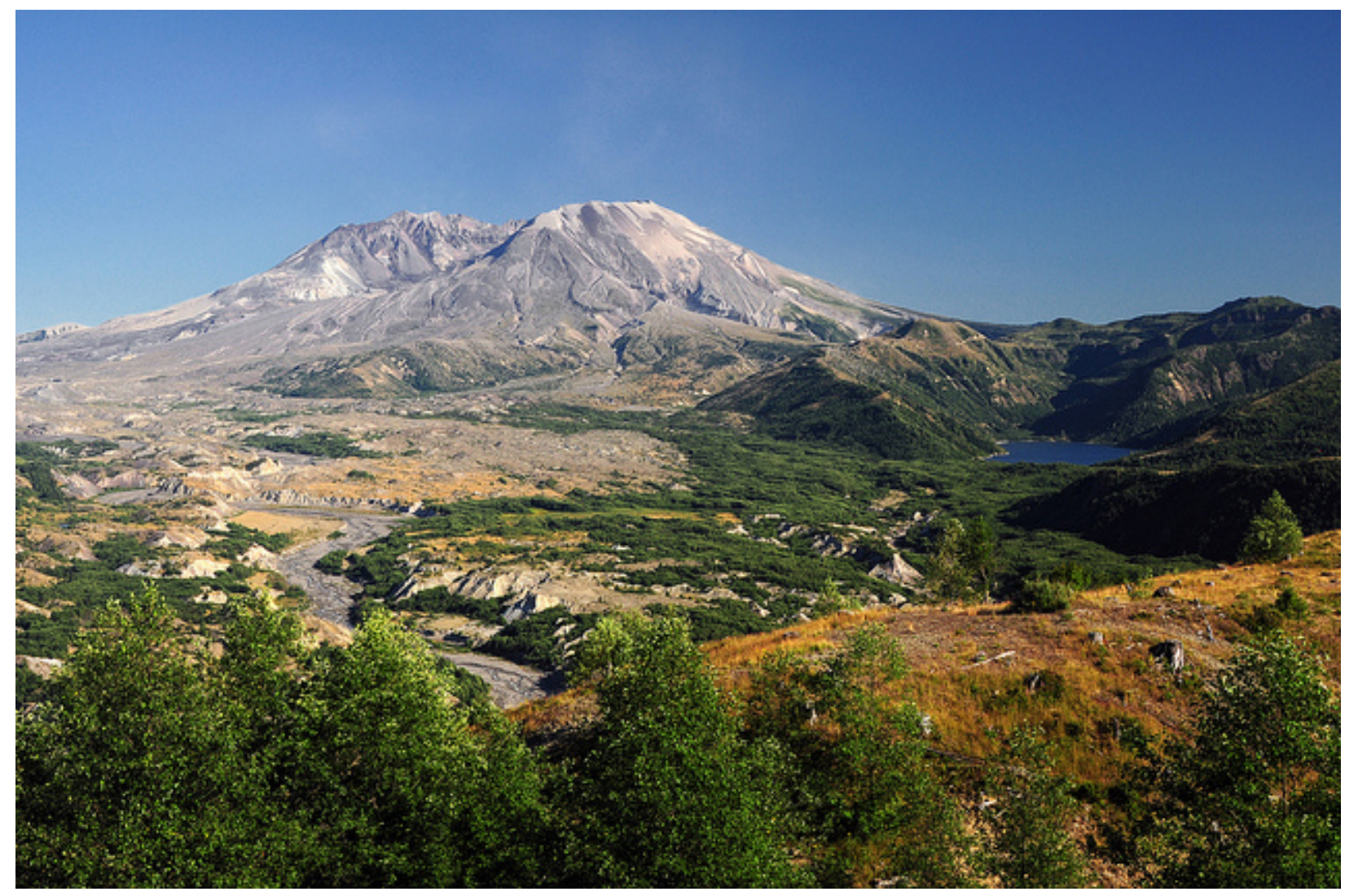

Figure 1. Photograph of Mount St. Helens and Castle Lake upstream of the Sediment Retention Structure on the North Fork Toutle River, Washington. The braided channel of the Toutle River, which originates in the crater of Mount St. Helens, is in the lower middle part of the photograph. The blockage forming Castle Lake was emplaced during the catastrophic debris avalanche on May 18, 1980. The blockage is now vegetated but is permeable. The Castle Lake outlet now feeds a tributary of the North Fork Toutle River. 


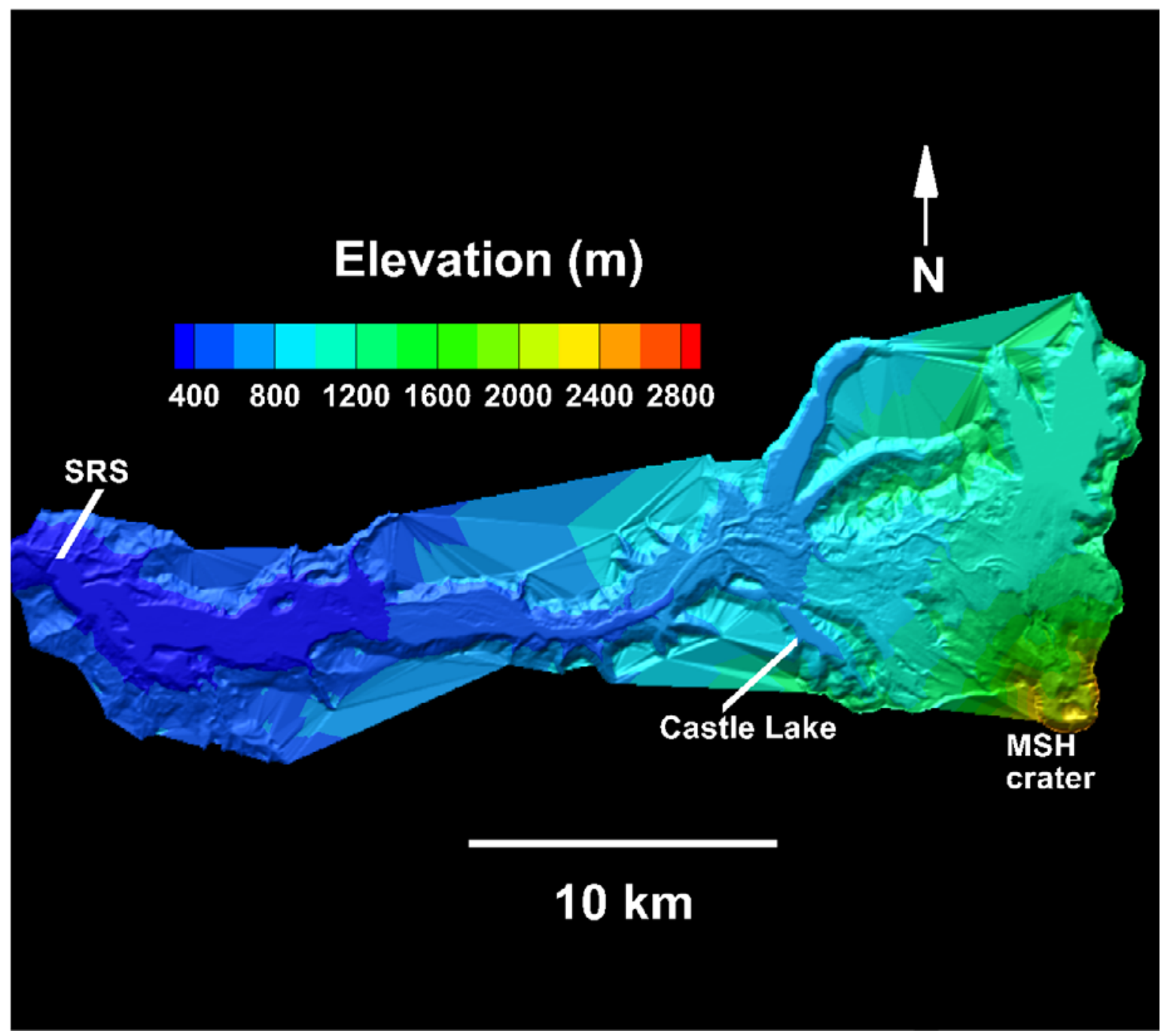

UTM $=$ 10NNorth American Datum of 1983 with $\mathrm{x}=527800$ and $y=5102800$ substracted from distance east and distance north.

Figure $2 A$. Shaded-relief map of numerical domain used for flow simulations. Elevation data are from LiDAR mapping of this region (Watershed Sciences, 2009, unpub. data), and have been generalized to a 50 -meter cell size for the flow calculation. The impact of a 50 -meter cell size generalized on grid discretization near the spillway is shown in figure $2 B$. 


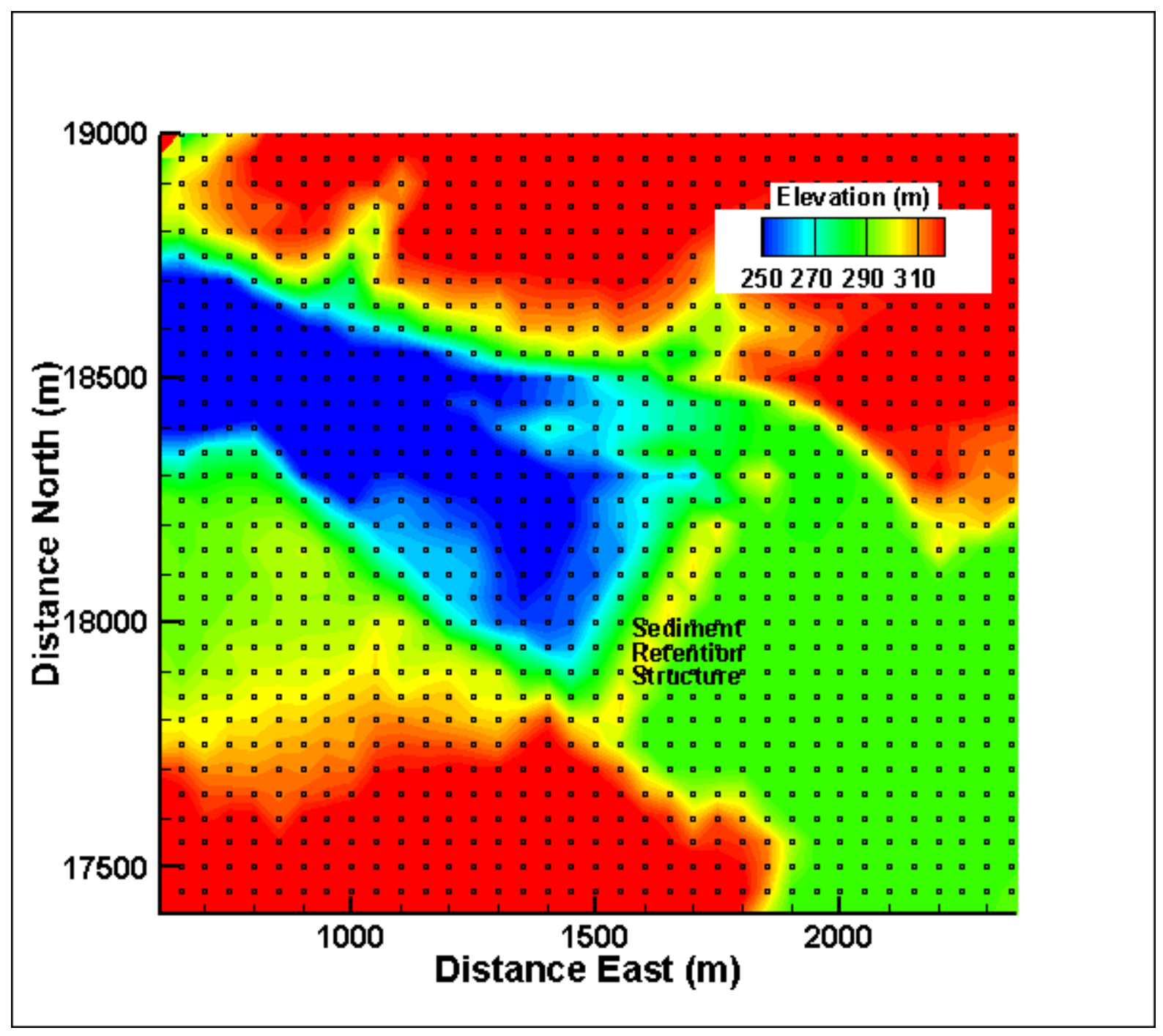

Figure 2B. Close-up image of Sediment Retention Structure (SRS) as it is discretized in the numerical domain, with the elevation of each point shown with flooded contours. Each black square is the center of a computational cell on the numerical grid, which has a spacing of 50 meters. The spillway of the SRS is adequately sampled.

\section{Methods}

Two specific conditions were modeled, reflecting the impact of inundation, either from debris flows or from sediment-laden floods. The distinct physical properties and behaviors associated with these flow types require different modeling approaches.

Shallow water flooding: For numerical modeling of the sediment-laden water floods, analysis was based on a depth-averaged model for flow of shallow water over three-dimensional terrain with slopes up to 32 degrees (Denlinger and O’Connell, 2008). This model has been tested on flows in the U.S. Geological Survey (USGS) flume near Blue River, Oregon, and on catastrophic dambreak floods in France and the United States. This model accounts for non- 
hydrostatic forces resulting from flow over rugged terrain, making the algorithm appropriate for dambreak analyses of flows in the rugged topography of the upper Toutle River drainage.

Debris flow routing: Debris flows are mixtures of sediment and water with a variable amount of fine (silt and clay) material. At Mount St. Helens, most debris flows are composed of gravel, sand, and silt (Iverson, 1997). Numerical modeling of these flows over three-dimensional terrain is described in Denlinger and Iverson (2001), who did simulations of such flows in the USGS debris flow flume. The material properties assumed for the debris flows simulated here (table 1) are based on the bulk composition of the 1980 debris avalanche at Mount St. Helens. The composition of this avalanche is representative of debris flow material for flows affecting the upper North Fork Toutle River basin (Iverson, 1997; Glicken, 1998).

The equations used to model debris flows are similar to the shallow water equations used for flood routing (Denlinger and Iverson, 2001), but account for the substantially greater internal and boundary stresses than those achieved in water floods, even in sediment-laden floods. The numerical model is partly based on the condition that for flowing debris, intergranular fluid pressure, or 'pore pressure' typically increases to 90 percent of the overburden load at a few percent bulk shear strain (Iverson, 1997). Continued straining during flow regenerates internal pore pressures and allows saturated debris to continue to flow, but pressure in slow moving zones dissipates, inhibiting motion and promoting deposition (through cessation of flow). A kinematic condition given in Denlinger and Iverson (2001) defines patterns of pore pressure diffusion based on surface slope and flow movement, and typically enhances diffusion by an order of magnitude along advancing margins of the flow. With these conditions and a higher bulk density, observed and simulated debris flows accelerate and decelerate much more rapidly than water floods, particularly when flowing over steep terrain. Simulated debris flows mimic observed debris flows in that debris is stranded as levees along flow margins, often filling embayments along the channels they occupy.

A debris flow also can transition to sediment-laden water flow if it incorporates sufficient in-channel river water. Progressive dilution results in fewer enduring particle contacts among the granular debris composing the flow, and eventually the debris flow transforms into a water flow carrying fine-grained suspended load and a coarse bed load. This typically occurs at a fluid/solid ratio of 50-60 percent by volume. Although dilution is gradual, the transition from a debris flow to a flood can be quite abrupt as the ratio of water to sediment increases (Denlinger and others, 2001). Because this transformation is not yet predictable and quantifiable, this study assumes that flows are either sediment-laden water floods or debris flows that do not transform within the study area. 
Table 1. Material properties and dimensionless parameters for model debris flow predictions. $\left[\mathrm{kg} / \mathrm{m}^{3}\right.$, kilogram per cubic meter; $\mathrm{m}^{2}$, square meter; $\mathrm{m}^{2} / \mathrm{s}$, square meter per second]

\begin{tabular}{ll}
\hline \multicolumn{1}{c}{ Property or parameter } & \multicolumn{1}{c}{ Value } \\
\hline & \\
Basal friction angle & 30 degrees \\
Internal friction angle & 30 degrees \\
Solid volume fraction & 60 percent \\
Fluid volume fraction & 40 percent \\
Fluid viscosity & 0.1 poise \\
Solid density & $2,600 \mathrm{~kg} / \mathrm{m}^{3}$ \\
Fluid density (muddy water) & $1,200 \mathrm{~kg} / \mathrm{m}^{3}$ \\
Hydraulic permeability & $10^{-11} \mathrm{~m}^{2}$ \\
Hydraulic diffusivity & $10^{-4} \mathrm{~m}^{2} / \mathrm{s}$ \\
Initial pore pressure/weight & $1,200 /, 2600$ \\
Maximum pore & 0.9 \\
pressure/weight & \\
\hline
\end{tabular}

\section{Numerical Model}

To apply either the shallow water flow model or the debris flow model to the flow simulations, a $2 \mathrm{~m}$ regular grid from LiDAR elevation data was constructed for the Mount St. Helens region (Watershed Sciences, 2009, unpub. data). The numerical domain, constructed from LiDAR data (from Watershed Sciences, 2009, unpub. data), is in UTM zone 10N (NAD83) and has $\mathrm{x}=527800$ and $\mathrm{y}=5102800$ (in meters) subtracted from the distance east and distance north, respectively, in all figures in this report. This is done in the computation to improve resolution, and in all figures to make them easier to read. To accommodate computer memory limitations, the grid was generalized to a $50-\mathrm{m}$ cell size on a square mesh grid for the numerical modeling (fig. 2A). A closeup of the meshed domain in the vicinity of the SRS and its spillway is shown in figure $2 \mathrm{~b}$. Flows on this three-dimensional surface grid are routed by specifying an initial volume of water or saturated debris, either at Castle Lake or in the crater of Mount St. Helens, and then applying the applicable numerical modeling scheme to let the flow translate downstream. The terrain controls the path of the flow such that as the stage rises the flow will take a straighter path downstream, often cutting off point bars and meanders (Denlinger and others, 2001). Because flow direction depends on stage, the thalweg varies considerably with stage along the flood wave, particularly when flow occurs over rugged terrain. For debris flows and water floods, the terrain routes the flow in local downhill directions regardless of number of multiple channels or channel width. The boundary conditions for simulated floods allow them to run off the grid downstream of the SRS without affecting flow upstream.

Four distinct scenarios were modeled: Two different-sized water floods from different scenarios of breaching of Castle Lake; another considered a debris flow from Castle Lake; and the fourth was a debris flow originating from the crater area of Mount St. Helens.

\section{Initial Conditions}

Dambreak from Castle Lake at controlled elevation: This scenario entails breaching of the impounded lake associated with the current, controlled, lake elevation but resulting in complete emptying of the lake. The total volume of water and sediment are derived from U.S. Army Corps of Engineers (1990) and assumes a limited 100-m wide breach channel on the southeastern side of the blockage with the channel bottom even with the lake bottom (fig. 3). 
This scenario produces a total flood volume of $28 \times 10^{6} \mathrm{~m}^{3}$, and includes $4.6 \times 10^{6} \mathrm{~m}^{3}$ of sediment incorporated from failure of the breach.

Full Dambreak from Castle Lake: This worst-case scenario assumes that the controlled outlet is somehow blocked, resulting in an elevated lake of $804 \mathrm{~m}$ that overtops the blockage prior to breaching. Instantaneous failure was assumed to accompany water overtopping the blockage, allowing release of the entire volume of blockage, down to the current elevation of the lake bottom. This scenario results in a total flow volume of $56 \times 10^{6} \mathrm{~m}^{3}$, which includes material entrained from the blockage. This worst case scenario tests the spillway capacity of the SRS to pass an anomalously large flood in which the flow does not damage the spillway.

Debris Flow from Castle Lake blockage: Given the amount of water in Castle Lake, it is implausible that failure of the blockage will produce a large debris flow rather than a flood. Nonetheless, it is useful to look at the difference between a large debris flow originating at Castle Lake, and a large flood resulting from failure of the blockage. Here, I defined how much volume comprises the blockage at Castle Lake using the results from U.S. Army Corps of Engineer (1990). The base of the blockage was even with the level of the lake bottom (as with the full dambreakscenario). Computationally, I did not include water and debris in a single simulation, so I assumed that the lake and blockage formed $28 \times 10^{6} \mathrm{~m}^{3}$ of saturated debris with the geometry shown in figure 3 and the properties in table 1.

Debris Flow from Mount St. Helens crater: This scenario assumes mobilization of an arbitrary brick with $25.4 \times 10^{6} \mathrm{~m}^{3}$ of saturated debris sitting on the floor of the crater (fig. 4). The volume of this simulated flow is a worst-case scenario as the volume used is much larger than the crater is likely to produce at this time (2012). This volume lies between the volumes of the two largest debris flows originating from Mount St. Helens since 1980 (65 million $\mathrm{m}^{3}$ on May 18, 1980, and 4 million $\mathrm{m}^{3}$ on March 19, 1982 (Tilling and others, 1997). The initial cubic geometry of the debris flow volume in the crater at Mount St. Helens is not critical, because any debris volume flows and changes shape within a few hundred meters in response to valley and channel geometry as well as in response to internal pore pressure fluctuations. For this scenario, the initial volume (fig. 4) was fully saturated but not pressurized, and pore pressure was calculated to develop completely at 1 percent bulk shear strain as debris flowed downhill. 


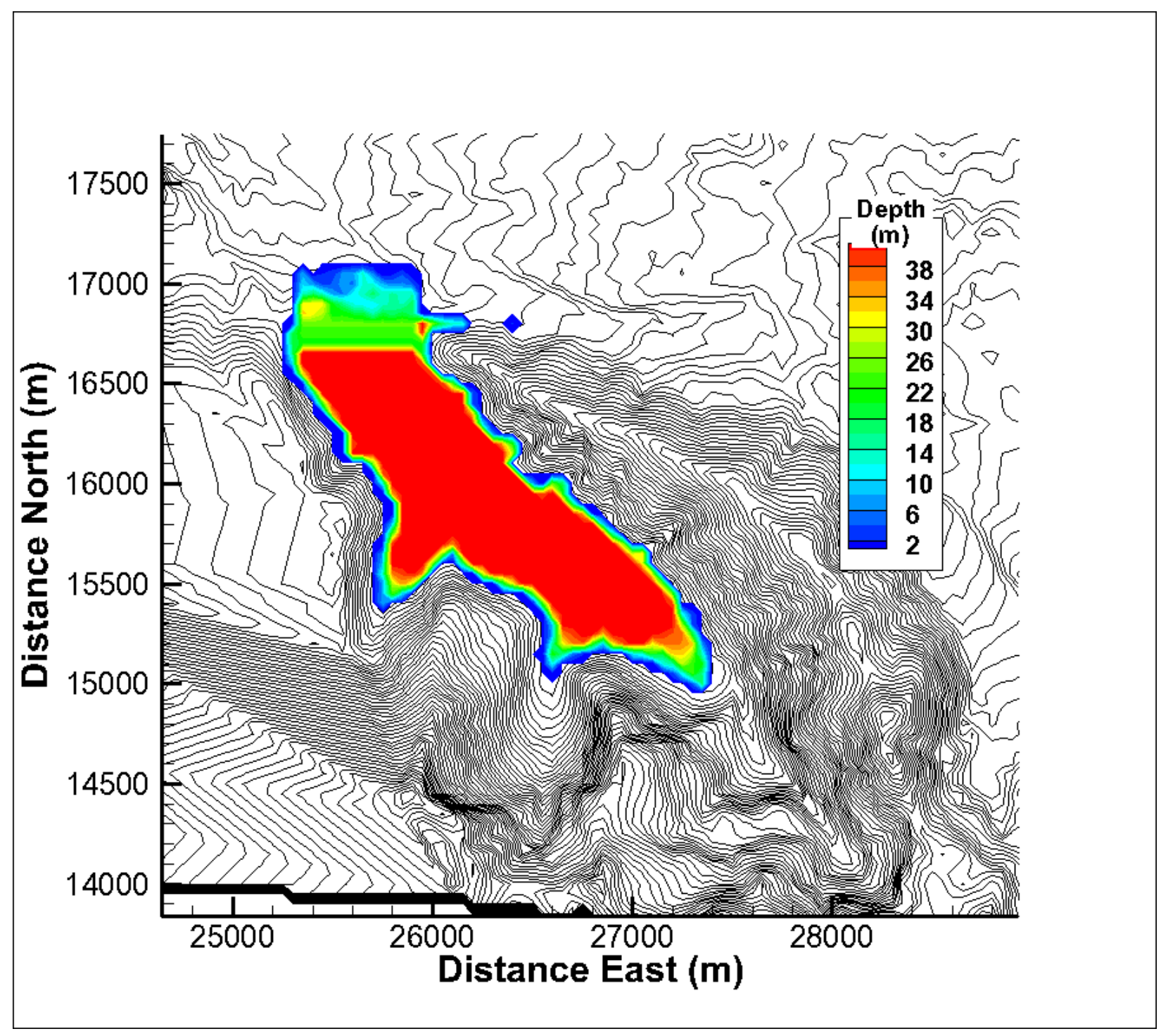

Figure 3. Initial condition for Castle Lake and blockage. The blockage was formed by the debris avalanche of May 18, 1980, and produced the lake by damming a tributary of the North Fork Toutle River. The terrain model is based upon LiDAR mapping of the surrounding region (Watershed Sciences, 2009, unpub. data), and the thickness of the blockage is determined from U.S. Army Corps of Engineers (1990) studies of Castle Lake. For a partial dambreak, the normal lake depth of 21 meters is used, giving a total flow volume of $28 \times 10^{6}$ cubic meters, which includes $5 \times 10^{6}$ cubic meters of blockage material. For a larger dambreak assuming blockage of the controlled outlet, the maximum initial depth is 41 meters and the total volume is $56 \times 10^{6}$ cubic meters. See text for explanation of UTM datum. 


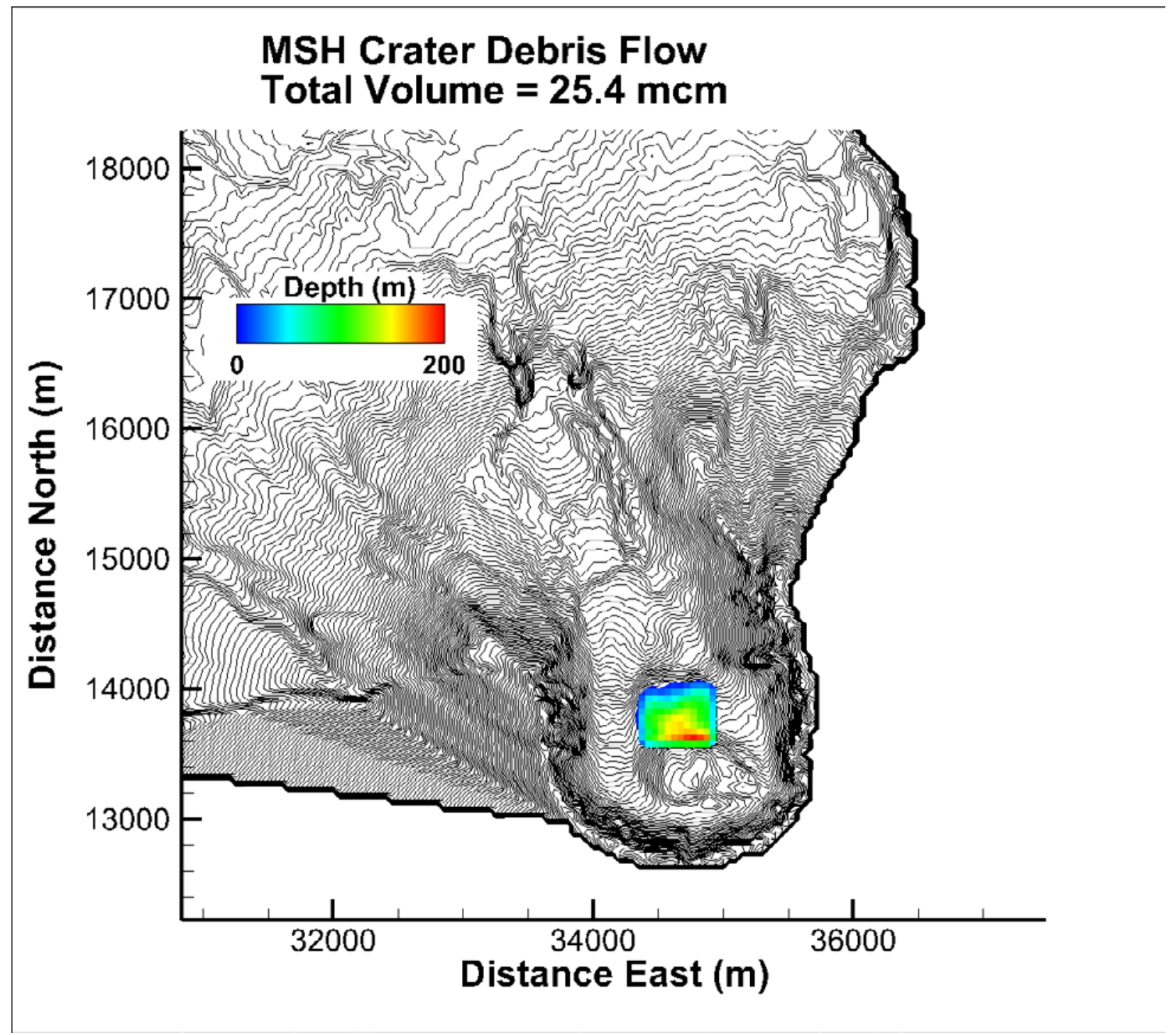

Figure 4. Initial conditions assumed for a debris flow from the crater of Mount St. Helens. The initial unrealistic prism shape for the debris flow mass does not affect results because the flow will quickly evolve in accordance to downstream topography. The volume of the flow is close to the maximum volume observed for debris flows originating in the crater of Mount St. Helens since 1980. See text for explanation of UTM datum.

\section{Results and Analysis}

The model simulations indicate that all scenarios result in substantial flow volumes and discharges into the drainage system of the North Toutle River upstream of the SRS. The potential effects of these simulated flows on the SRS depend on whether the flow reaches the dam and whether the stage at the dam exceeds spill capacity and overtops the dam crest. Additionally, long-term decreases in storage capacity may result from deposition behind the SRS. The various scenarios have different outcomes with respect to these issues. 
Dambreak floods from Castle Lake: The differences between the controlled elevation and full dambreak floods from Castle Lake owe to the rate at which water is released from the lake and the total volume of the flood. The differences in the opening in the blockage between these two scenarios control the rate of release, and the differences are apparent in the resulting flow soon after failure of the blockage (figs. 5 and 6). A large opening (full dambreak) has a high rate of discharge and a much greater effect on the outlet channel at early in the simulation. As the dambreak flood wave lengthens, the differences between the two scenarios result primarily from total volume released (figs. 7-10). A high discharge into the Toutle River valley results from the enhanced volume of $56 \times 10^{6} \mathrm{~m}^{3}$ of water and sediment produced by the full dambreak scenario. In this case, the model predicts a peak discharge of $40,000 \mathrm{~m}^{3} / \mathrm{s}$ in the Toutle River Valley upstream of the SRS (fig. 11); however, this peak discharge is attenuated within the wide Toutle River valley and by existing storage capacity of the SRS, such that the peak discharge at the SRS is only $6,000 \mathrm{~m}^{3} / \mathrm{s}$ and is predicted to pass through the spillway without overtopping the crest of the SRS dam. That the dam does not overtop with such a huge input discharge upstream is testimony to the huge conveyance in the Toutle River valley. As the flow at the spillway crests at $6,000 \mathrm{~m}^{3} / \mathrm{s}$, the water surface is still $3 \mathrm{~m}$ below the crest of the dam.

Debris flows from failure of Castle Lake blockage: An alternative scenario is given by the unlikely formation of a debris flow from failure of the blockage of Castle Lake. To demonstrate the impact of a large debris flow rather than a large flood, the model assumes the lake and blockage volume (fig. 12) combine to form saturated debris that flows downhill. The final condition is shown in figure 13. The debris flow stops before it reaches the SRS, but affects SRS storage capacity because debris fills in the braided channels upstream in the Toutle River valley. Filling and modification of the braided channels in this way is expected for all debris flows, whether the flows initiate at Castle Lake or in the crater of Mount St. Helens.

Debris flows from Mount St. Helens crater: Debris flows that initiate in the crater of Mount St. Helens are far more likely than a debris flow that initiates from failure of the Castle Lake blockage, but the results are similar. The impact and results are sensitive to the volume of the initial debris (fig. 4), but not the initial geometry (shown in figure 4 as a block). As the crater debris flow progresses downslope, material at the margins of the flow becomes stranded in embayments along the channels. Additionally, some of the initial debris is left behind as some flow is forced to completely pressurize (liquefy) the flow (Denlinger and Iverson, 2001). Farther downslope, the debris flow from the crater divides at the base of Mount St. Helens; about onehalf of the flow spreads east, entering Spirit Lake and forming a delta and about one-half proceeds down the Toutle River toward the SRS (figs. 14a and 14b). For these modeled conditions of a debris flow from the crater of Mount St. Helens, a total volume of $25 \times 10^{6} \mathrm{~m}^{3} / \mathrm{s}$ with specified physical properties (table 1 ) never reaches the SRS. The debris flow does partially fill the channel of the North Fork Toutle River upstream of the SRS and does leave deposits at embayments and bends in the channel (fig. 14). The full volume of the crater debris flow remains upstream of the SRS (fig. 15), with a large part of the flow coming to rest closer to the dam than did the simulated Castle Lake debris flow. Given the simulated excessively large, and unlikely, volume of debris flows from the crater, and the natural limit to the volume of debris flows from the blockage of Castle Lake; the simulations show that there is insufficient volume and regional slope for debris flows from either site to flow to or over the SRS structure without additional entrainment of water sufficient for these flows to transition to a water flood. In the long term, however, the deposits left by debris flows upstream of the SRS accumulate, increasing sediment 
loads in the channels feeding into the SRS. This reduces channel conveyance and increases flood hazards downstream.

Table 2. Table 2. Stage at Sediment Retention Structure (SRS) for different dambreak volumes. $\left[\mathrm{m}\right.$, meters; $\mathrm{Mm}^{3}$, million cubic meters]

\begin{tabular}{llc}
\hline \multicolumn{1}{c}{ Initial conditions and flood volume } & Maximum stage at SRS & Maximum depth at SRS \\
\hline Partial breach of Castle Lake, $28 \mathrm{Mm}^{3}$ & $297.0 \mathrm{~m}$ & $9.9 \mathrm{~m}$ (near spillway) \\
Full breach of Castle Lake, $56 \mathrm{Mm}^{3}$ & $299.8 \mathrm{~m}$ & $11.7 \mathrm{~m}$ (near spillway) \\
\hline
\end{tabular}

\section{Conclusions}

Extreme scenarios of debris flows and floods in the upper North Fork Toutle River drainage show that the Sediment Retention Structure (SRS) operated by the U.S. Army Corps of Engineers on the North Fork Toutle River in southwestern Washington, is still viable in its present form. Flows were simulated from either a partial or a complete failure of the blockage forming Castle Lake, as well as a large debris flow emanating from the crater of Mount St. Helens. The results show that current SRS spillway geometry is capable of passing large floods, due in large part to the huge conveyance of the Toutle River valley upstream. The valley feeding into the SRS is broad enough to absorb a transient peak flood discharge exceeding 40,000 cubic meters per second without generating an output discharge at the SRS large enough to overtop the crest of the dam. Unlike floods, simulated debris flows do not reach the dam and thus have no impact on the spillway. Debris flows with volumes up to 28 million cubic meters originating in the crater of Mount St. Helens or at Castle Lake spread out and fill the braided channels in the broad Toutle River valley upstream of the dam, stopping before they reach the dam. The debrisflow deposits reduce the sediment storage capacity of the SRS, and thus its ability to pass large floods in subsequent years.

\section{References Cited}

Denlinger, R.P., and O’Connell, D.R.H., 2008, Computing nonhydrostatic shallow-water flow over steep terrain: Journal of Hydraulic Engineering, v. 134, no. 11, p. 1590-1602.

Denlinger, R.P., and Iverson, R.M., 2001, Flow of variably fluidized granular masses across three-dimensional terrain-2. Numerical predictions and experimental tests: Journal of Geophysical Research, v. 106, no. B1, p. 553-566.

Denlinger, R.P., O’Connell, D.R.H., and House, P.K., 2001, Robust determination of stage and discharge-An example from the extreme flood on the Verde River, Arizona: American Geophysical Union Water and Science Application, v. 5, p. 127-146.

Glicken, H., 1998, Rockslide-debris avalanche of May 18, 1980, Mount St. Helens volcano, Washington: Geological Survey of Japan Bulletin, v. 49, p. 55-106.

Iverson, R.M., 1997, Physics of debris flows: Reviews of Geophysics, v. 35, no. 3, p. 245-296.

Major, J.J., and Mark, L.E., 2006, Peak flow responses to landscape disturbances caused by the cataclysmic 1980 eruption of Mount St. Helens, Washington: Geological Society of America Bulletin, v. 118, no. 7/8, p. 938-958, doi:10.1130/B25914.1. 
Roeloffs, E.R., 1994, An updated numerical simulation of the groundwater flow system for the Castle Lake Debris Dam, Mount St. Helens, Washington, and implications for dam stability against heave: U.S. Geological Survey Water-Resources Investigations Report 94-4075, 80 p.

U.S. Army Corps of Engineers, 1990, Numerical simulation of mudflows from hypothetical failures of the Castle Lake debris blockage near Mount St. Helens, WA: Final Project Report No. 90-05.

Tilling, Robert I., Topinka, Lyn, and Swanson, Donald A., 1997, Eruptions of Mount St. Helens_-Past, Present, and Future: U.S. Geological Survey General Interest Publication available at http://pubs.usgs.gov/gip/msh/

U.S. Geological Survey, 2012, USGS Surface-water data for Washington: National Water Information System, Web Interface, accessed January 9, 2012, at http://waterdata.usgs.gov/wa/nwis/sw.

Willingham, W.F., 2005, The Army Corps of Engineers' short-term response to the eruption of Mount St. Helens: Oregon Historical Quarterly, v. 106, no. 2 (Summer, 2005), p. 174203.

Watershed Sciences, 2009, Remote sensing of the North Fork Toutle River: U.S. Army Corps of Engineers.

U.S. Army Corps of Engineers, 2006. “LiDAR Remote Sensing Data Collection: North Fork Toutle River, Washington.” Datum: NAD83, State Plane Washington South (date of Flight Oct 21, 2006), data collection by Watershed Sciences, report date November 16.

Wolfe, E.W., and Pierson, T.C., 1995, Volcanic-hazard zonation for Mount St. Helens, Washington: U.S. Geological Survey Open-File Report 95-497, 12 p. 


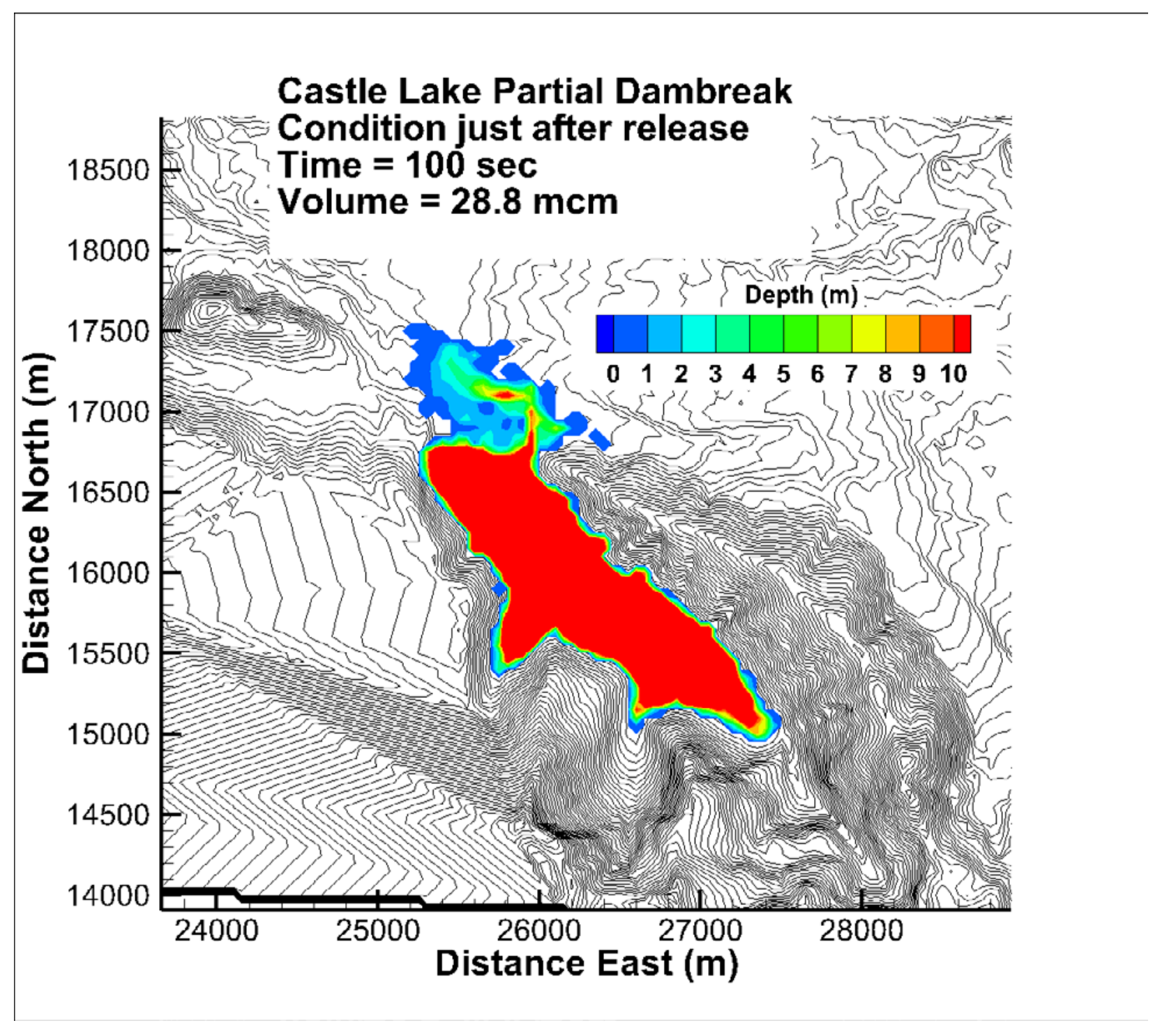

Figure 5. Initial flooding conditions associated with breaching of the blockage forming Castle Lake and spillway. Portrayed are model results at 100 seconds after failure where it was assumed that the failure forms a slot through the blockage, incorporates part of the blockage, and drains the entire lake. See text for explanation of UTM datum. 


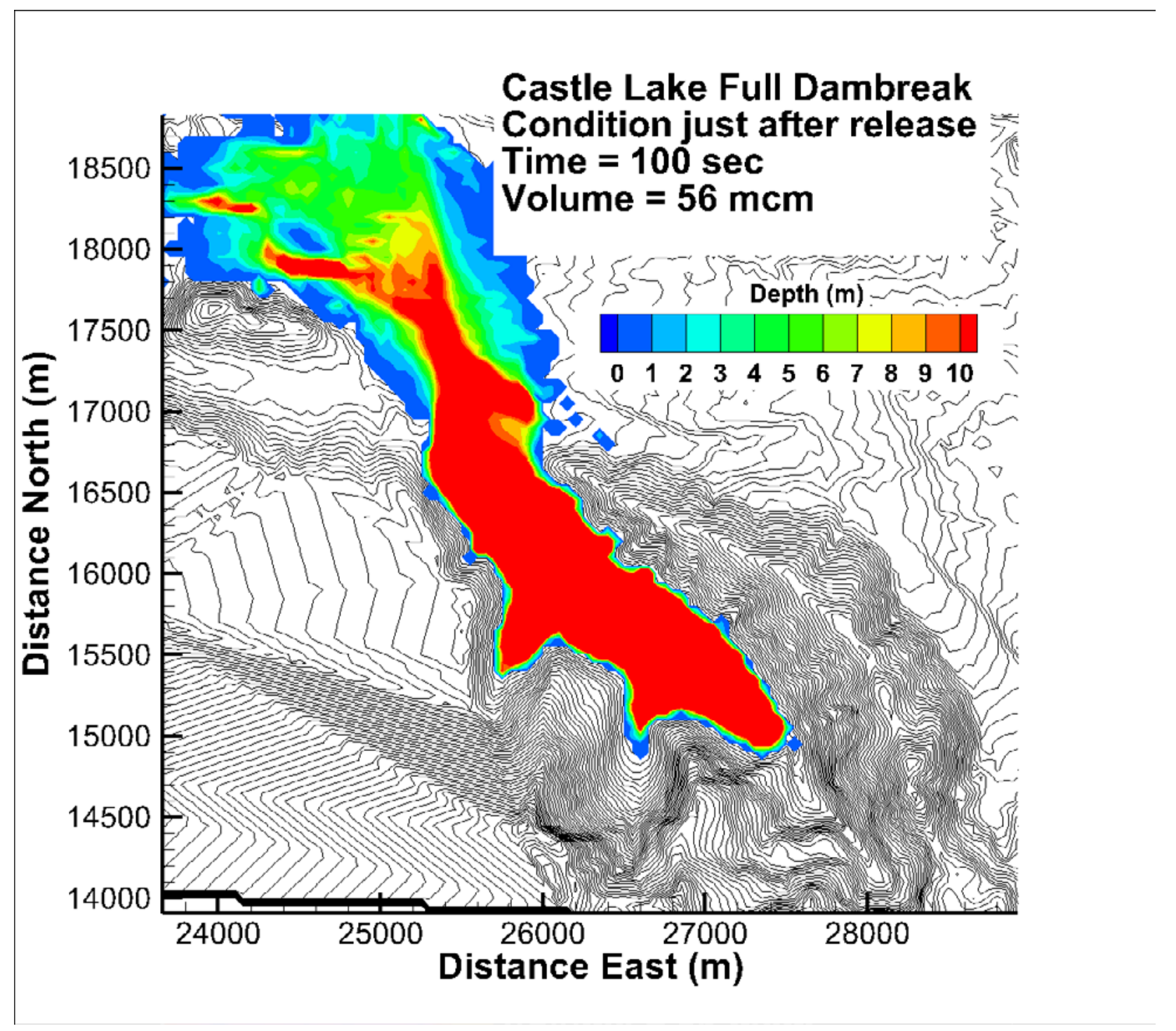

Figure 6. Initial flooding conditions associated with breaching of the blockage forming Castle Lake and spillway. This case represents the enhanced flooding conditions associated with a total volume of $5610^{6}$ cubic meters. Portrayed are model results at 100 seconds after failure where it was assumed that the failure forms a slot through the blockage, incorporates part of the blockage, and drains the entire lake. See text for explanation of UTM datum. 


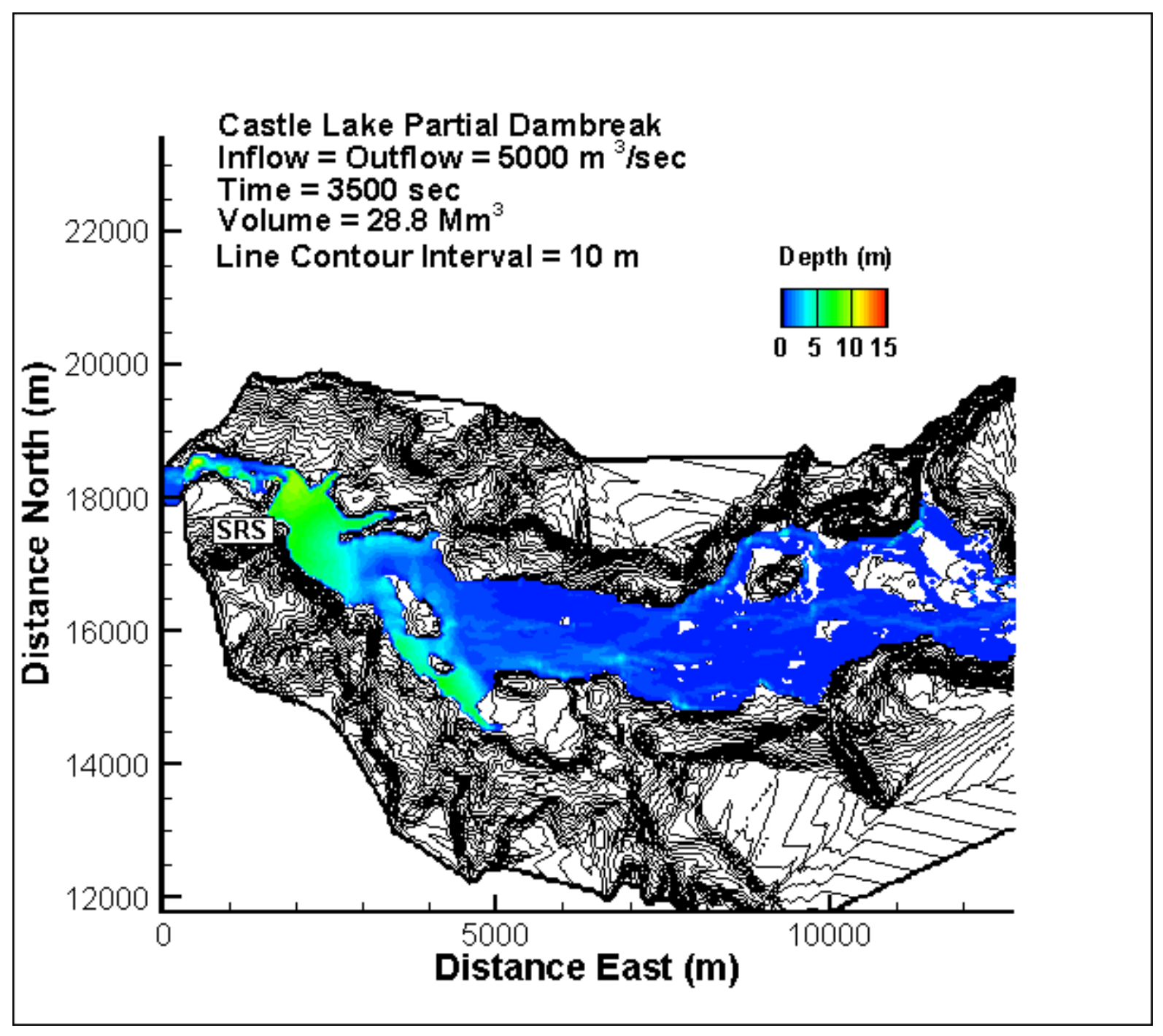

Figure 7. Water depth at peak stage at the dam, as steady flow is achieved through the Sediment Retention Structure. See text for explanation of UTM datum. 


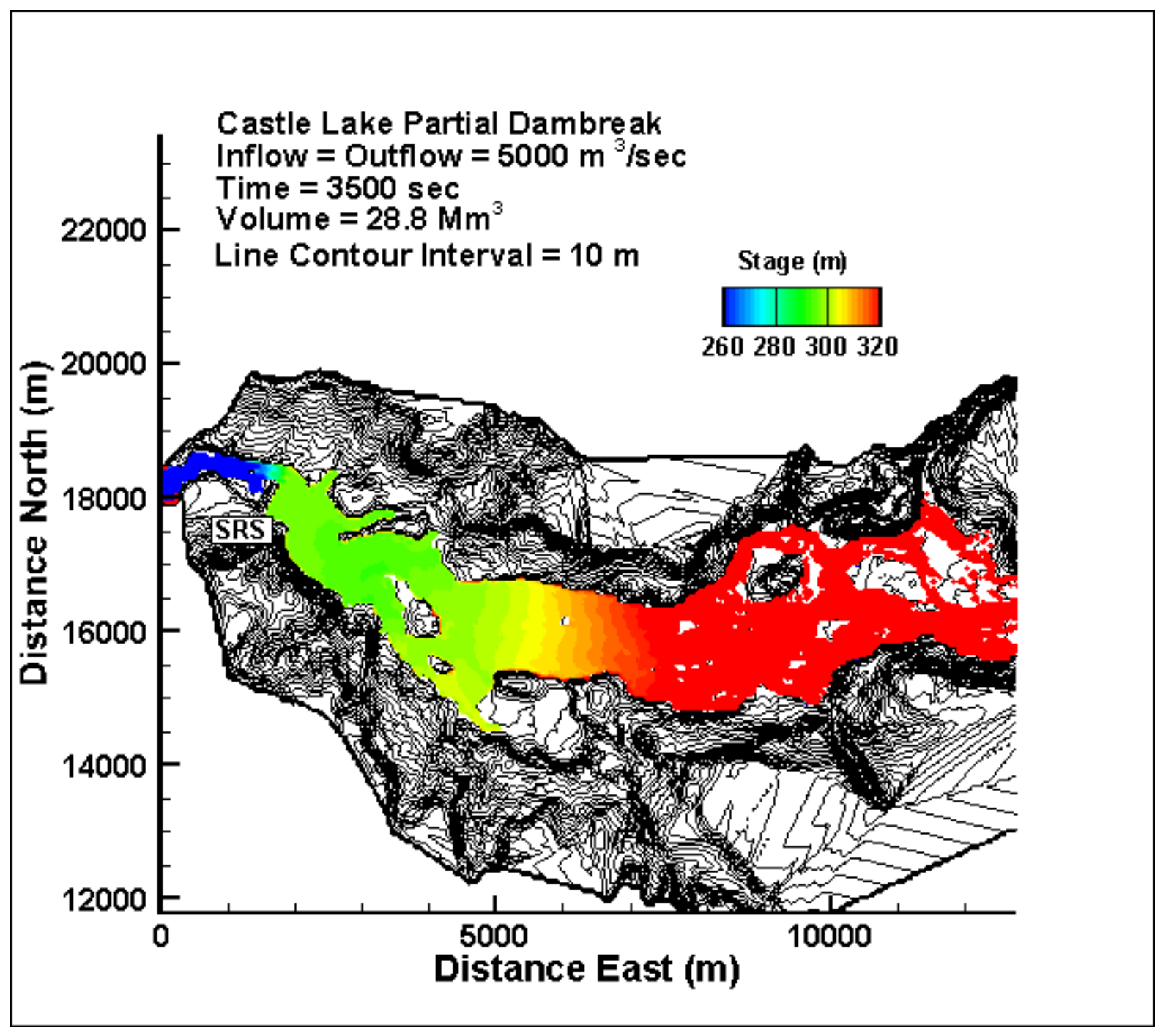

Figure 8. Peak water surface elevation (stage), as steady flow is achieved through the Sediment Retention Structure for a partial dambreak flood from Castle Lake and a total flow volume of 29 million cubic meters (23 million cubic meters of lake water plus 6 million cubic meters of blockage material). See text for explanation of UTM datum. 


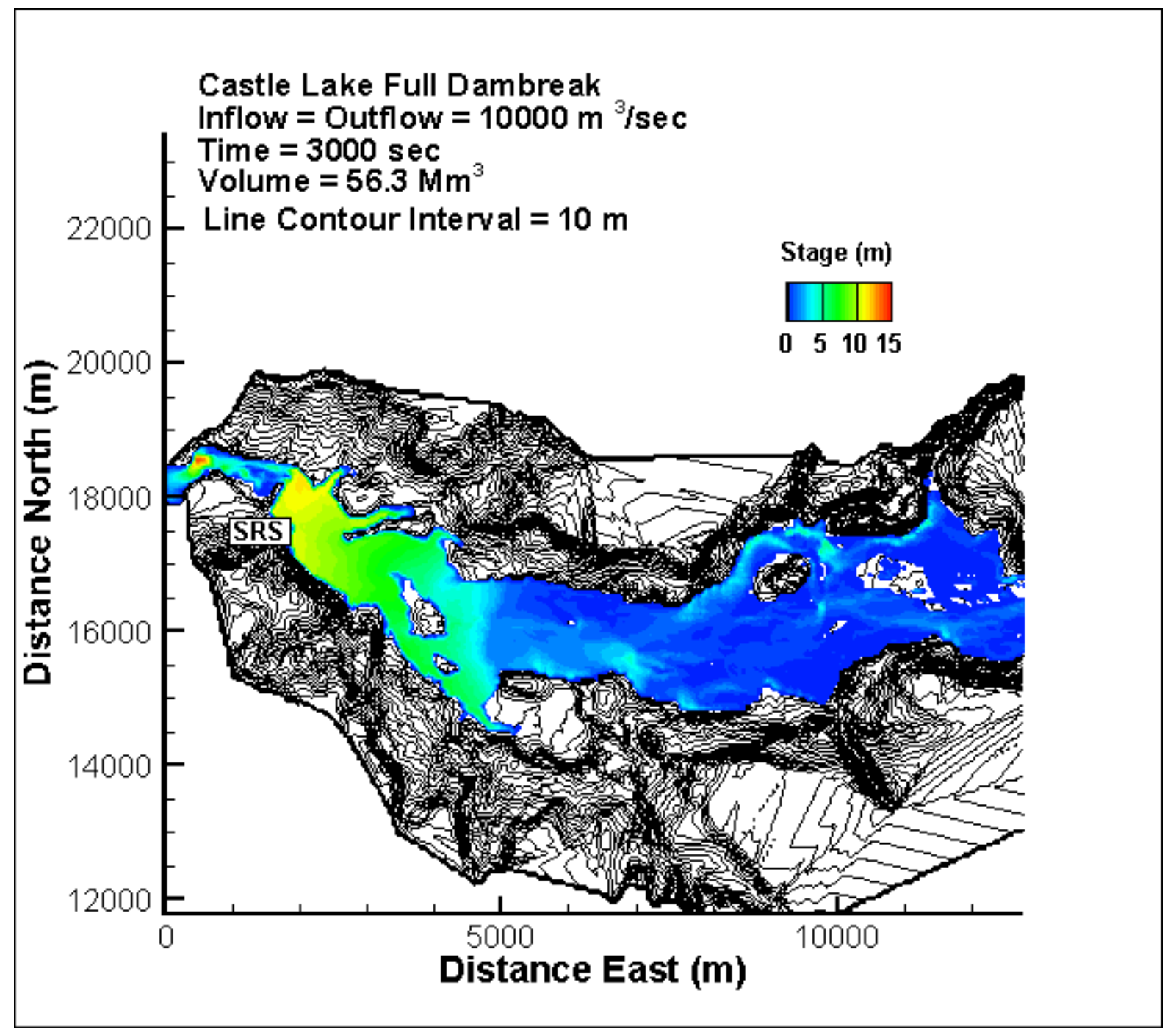

Figure 9. Water depth at peak stage at the dam, as steady flow is achieved through the Sediment Retention Structure for a dambreak flood from complete failure of the blockage of Castle Lake. Here, 46 million cubic meters comes from the lake and 10 million cubic meters from fluidized blockage volume. See text for explanation of UTM datum. 


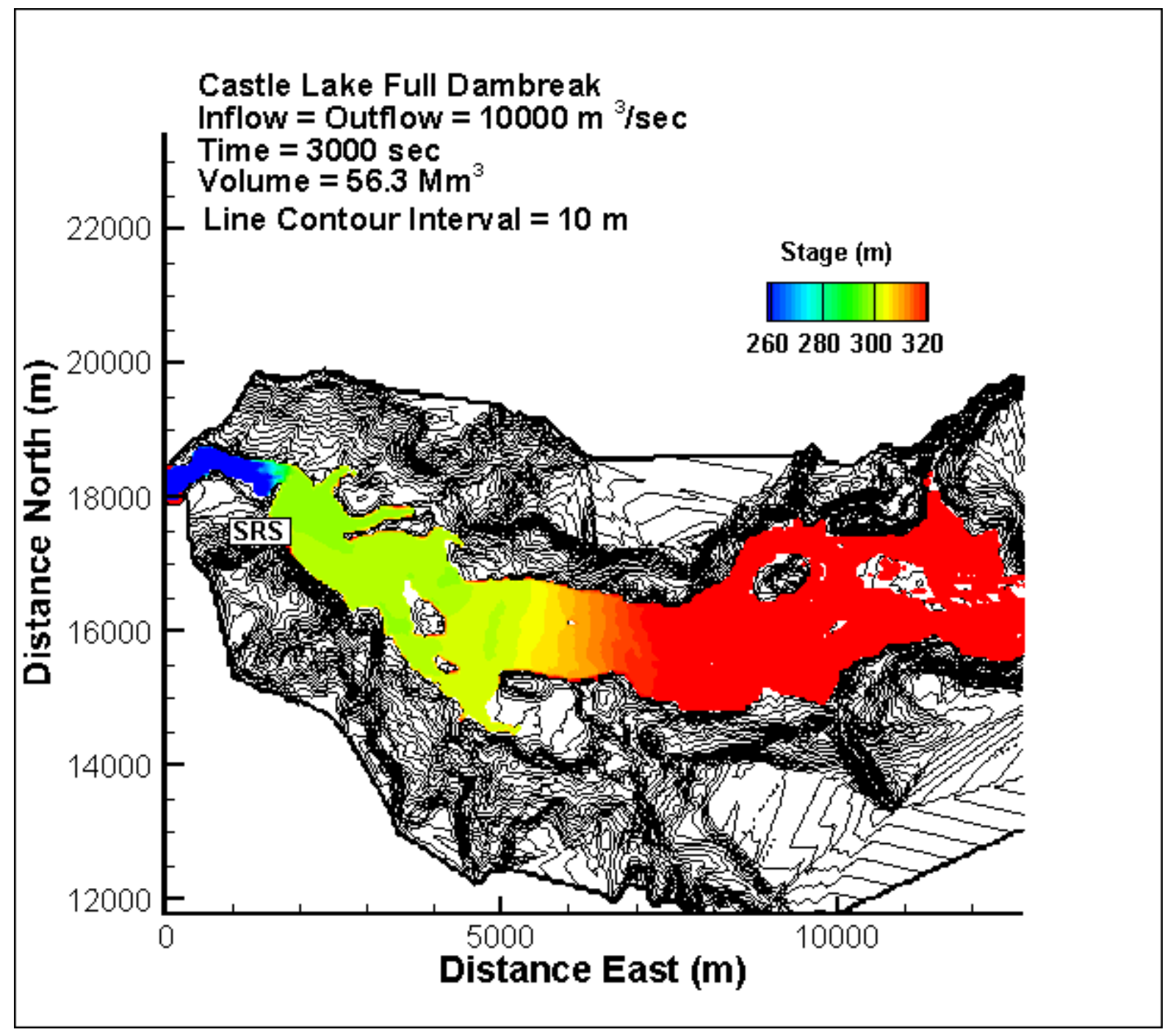

Figure 10. Peak water surface elevation (stage), as steady flow is achieved through the Sediment Retention Structure for a full dambreak flood from Castle Lake and a total flow volume of 56 million cubic meters (46 million cubic meters of lake water plus 10 million cubic meters of blockage material). See text for explanation of UTM datum. 


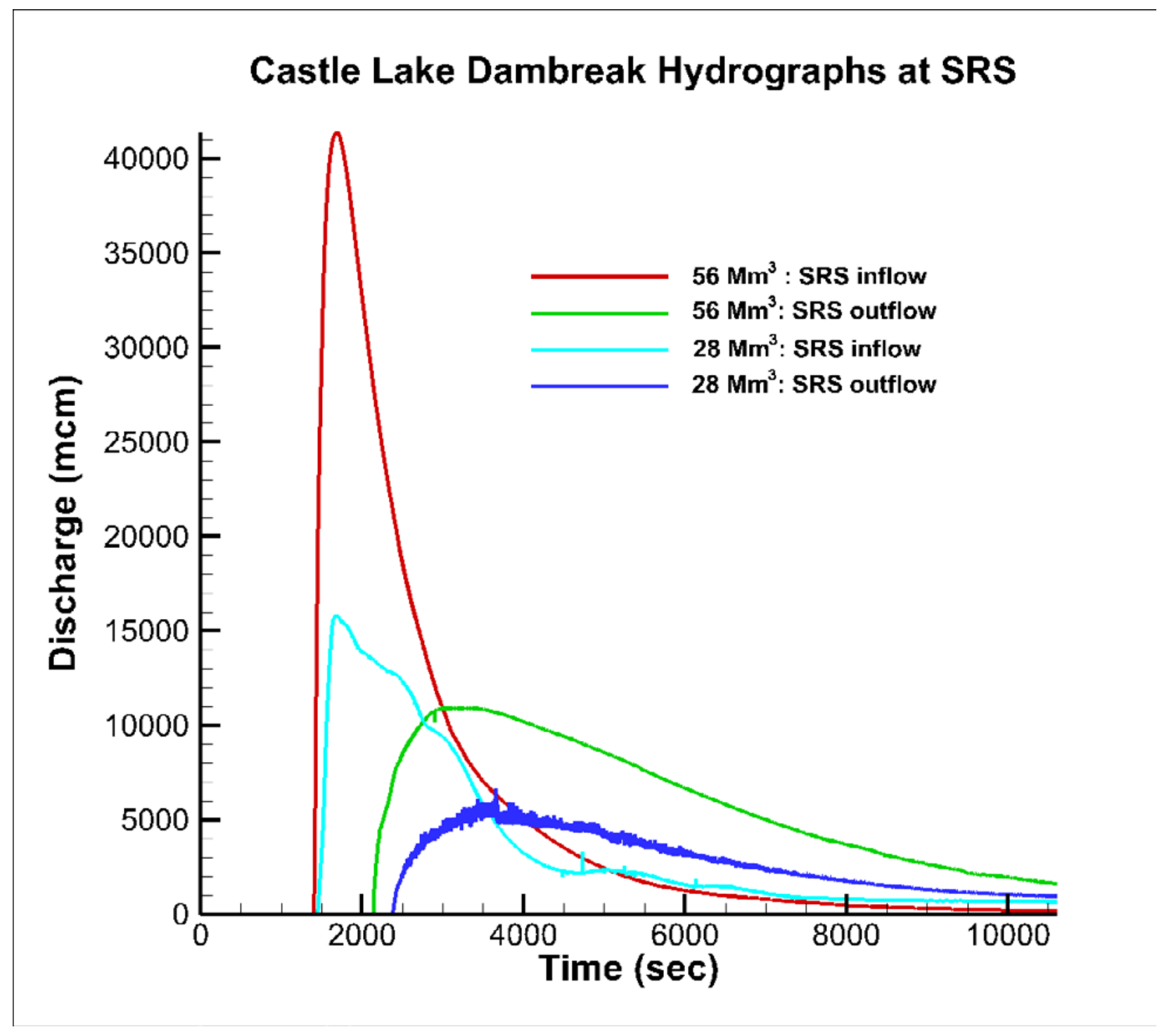

Figure 11. Hydrographs for both partial and complete failure of the blockage of Castle Lake, producing a dambreak flood that impacts the Sediment Retention Structure. The complete failure produces a much larger flow volume and a huge discharge into the channel of the North Toutle River upstream of the Sediment Retention Structure. 


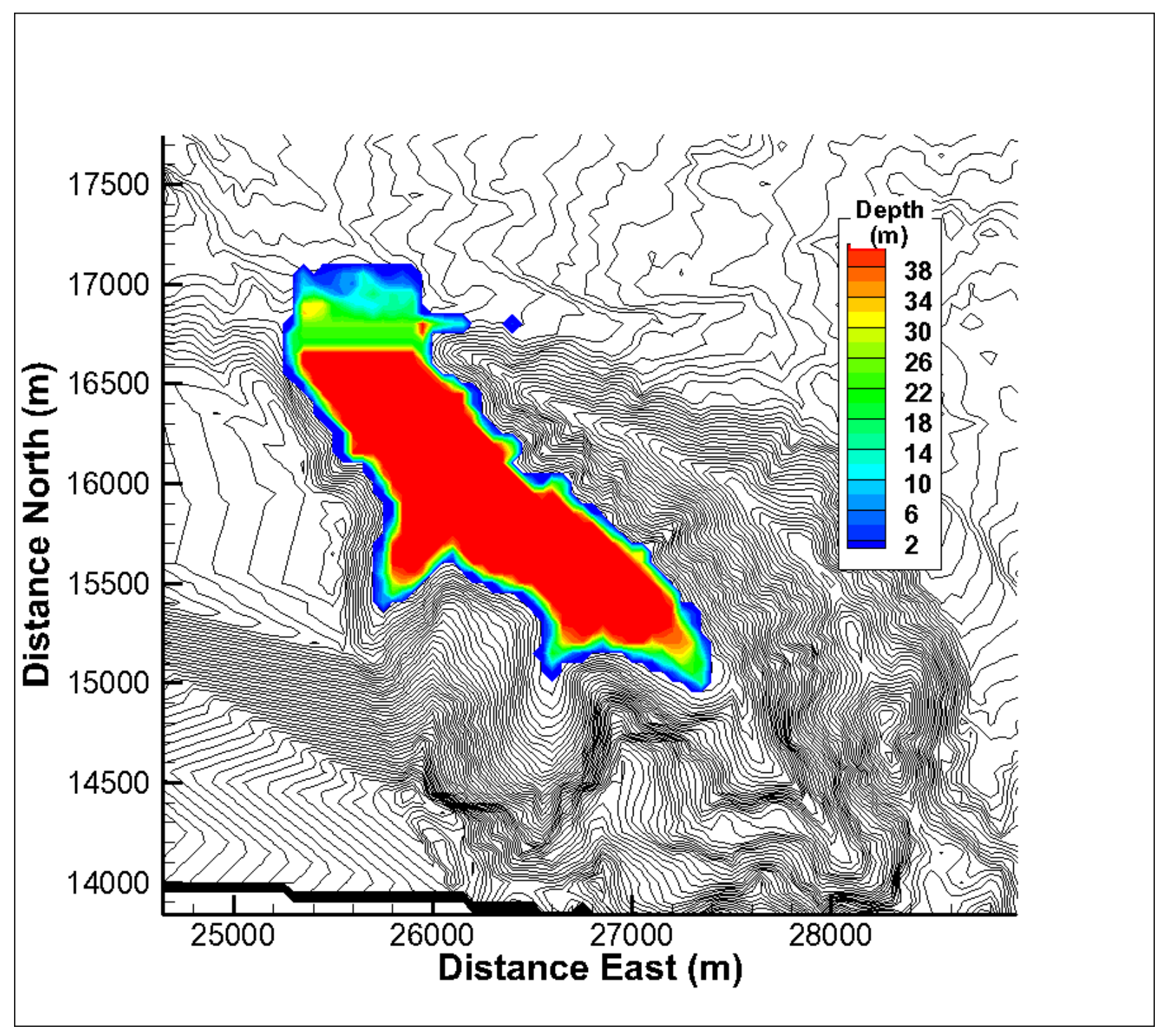

Figure 12. Initial conditions for a debris flow formed from the blockage and lake volume, where outlet is blocked and lake volume is assumed to be fluidized debris to a depth of 41 meters, giving a total volume of 56 million cubic meters. See text for explanation of UTM datum. 


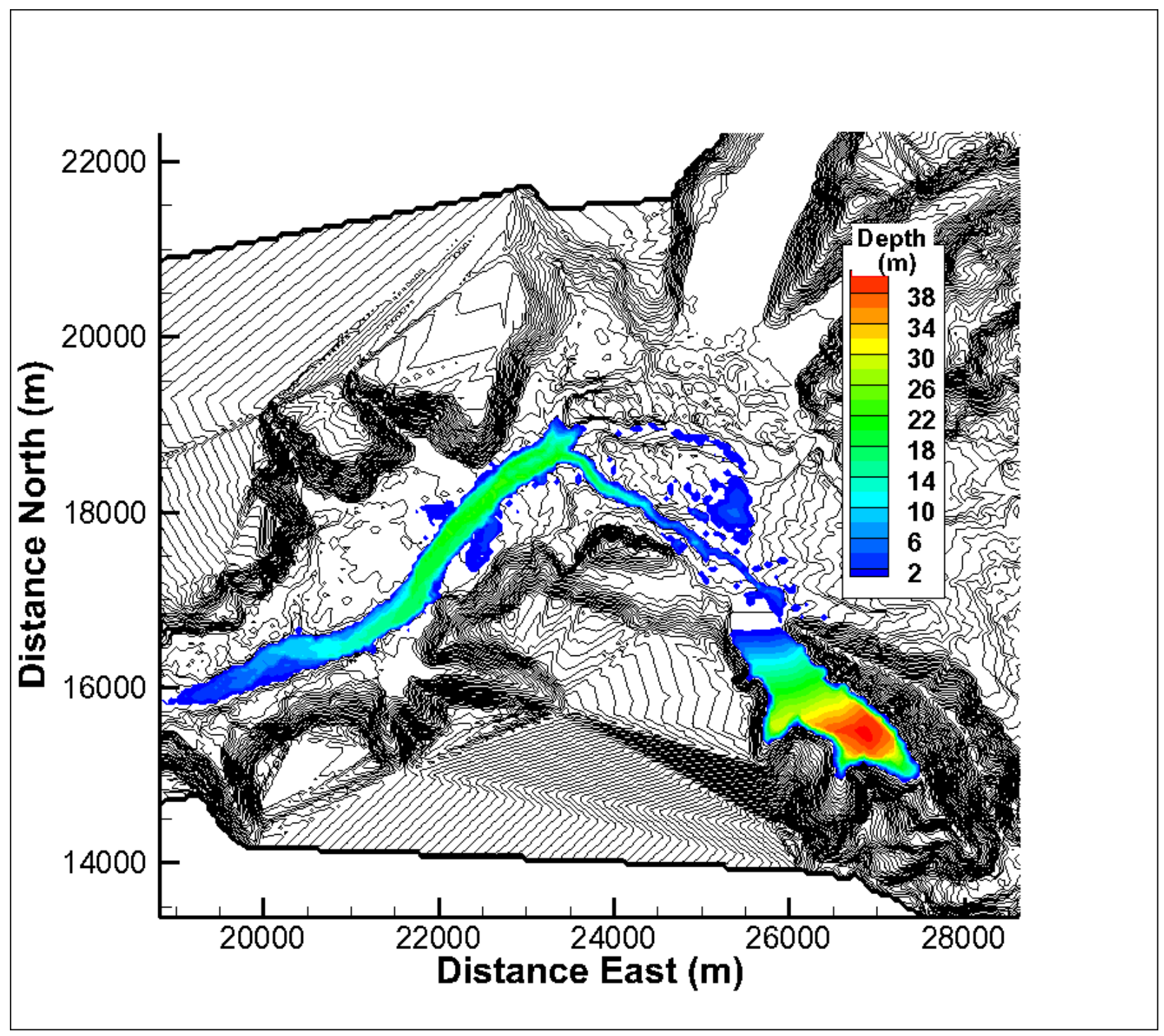

Figure 13. Final deposit for a debris flow with the initial configuration in figure 12. Despite the huge initial volume for the debris flow, the flow comes to rest before reaching the Sediment Retention Structure, and fills the channels of the North Fork Toutle River upstream of the dam. See text for explanation of UTM datum. 


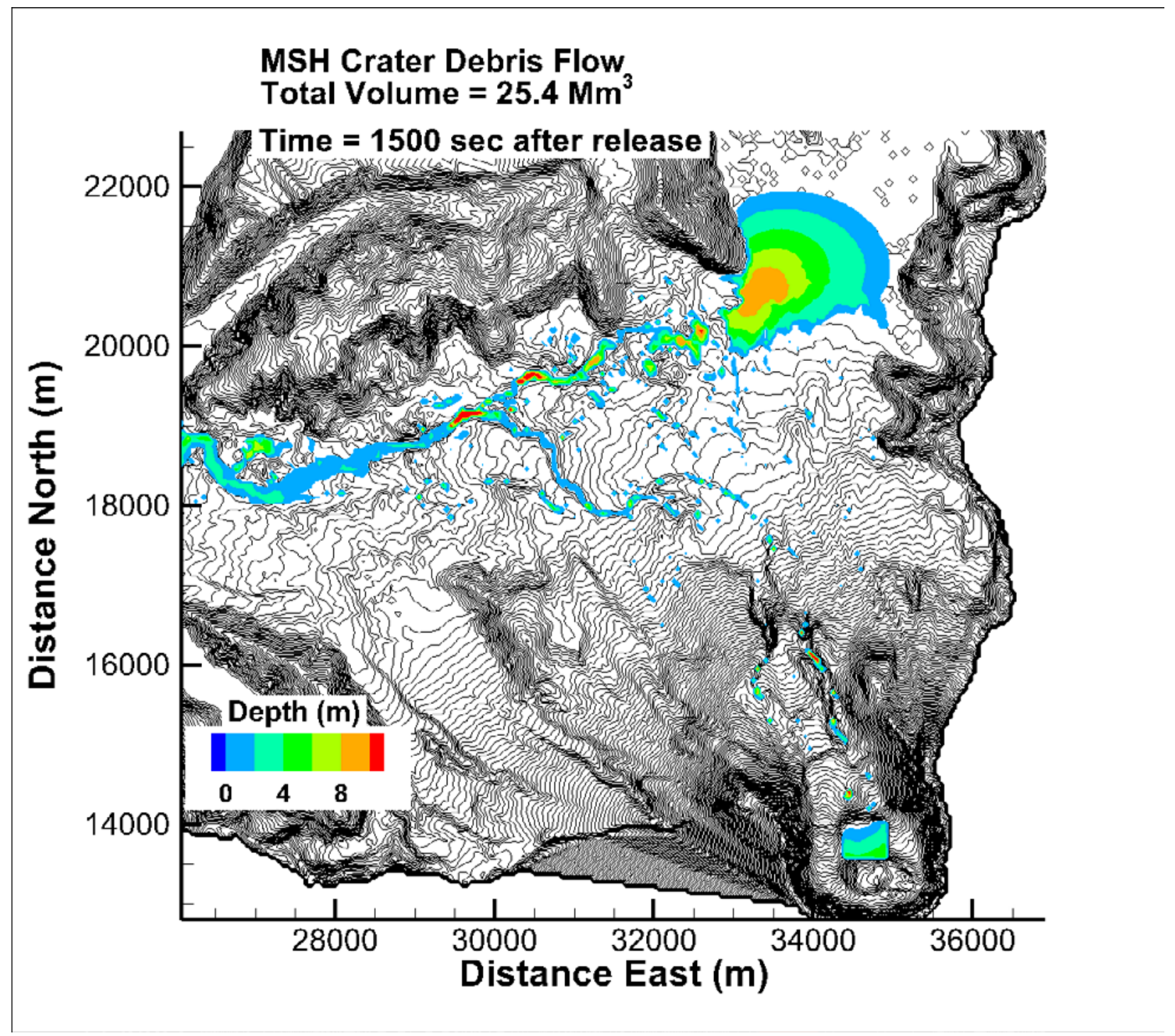

Figure 14A. Snapshot of flow depths of hypothetical crater debris flow 1,500 seconds after release. The debris flow has split into two parts; one part forms a delta on Spirit Lake, the other part continues down the North Fork of the Toutle River towards the Sediment Retention Structure. See text for explanation of UTM datum. 


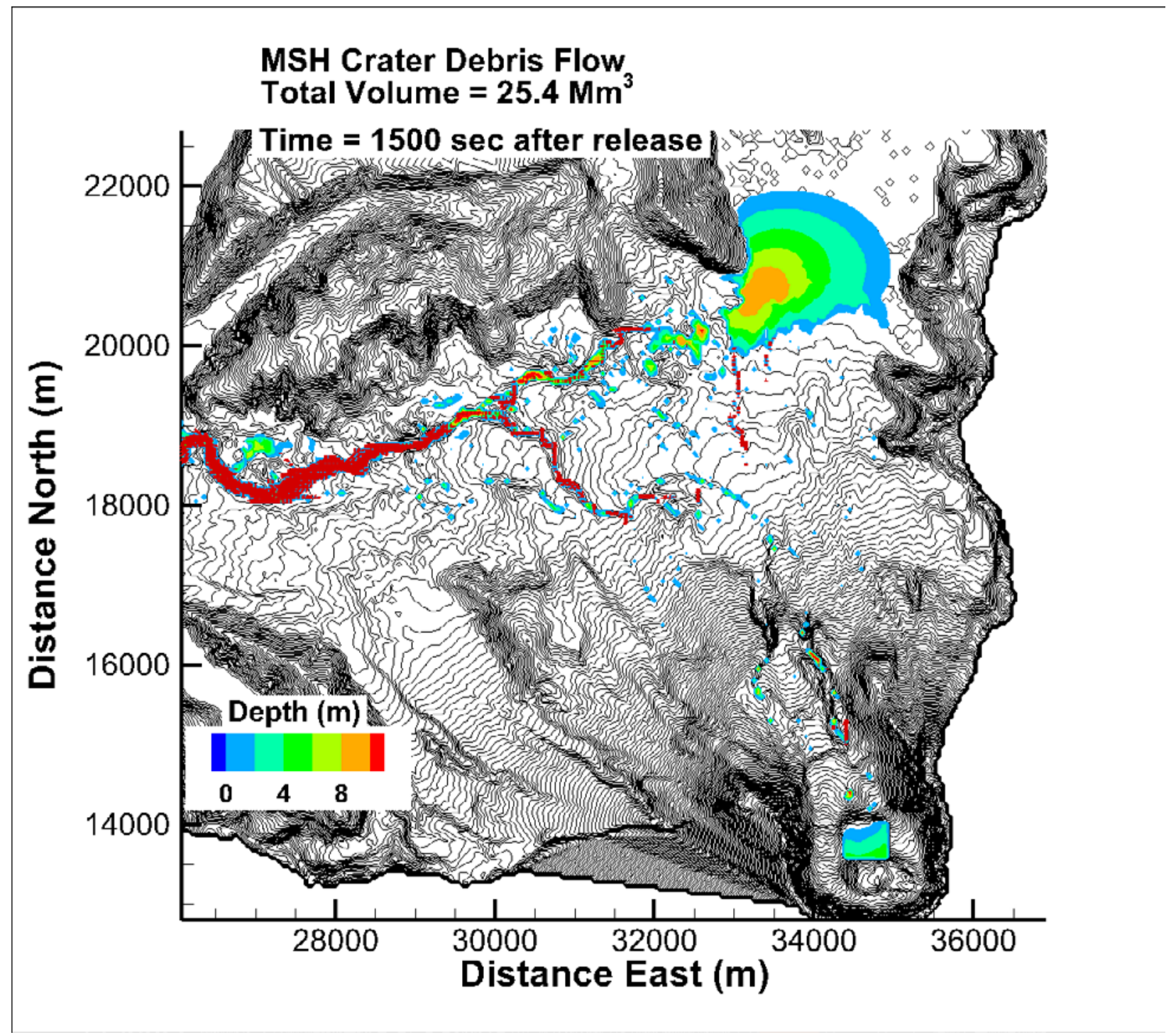

Figure 14B. Snapshot of flow depth of hypothetical crater debris flow 1,500 seconds after release. The dark red coloration shows which portions of the flow are still moving: the remainder of the debris is stagnant. See text for explanation of UTM datum. 


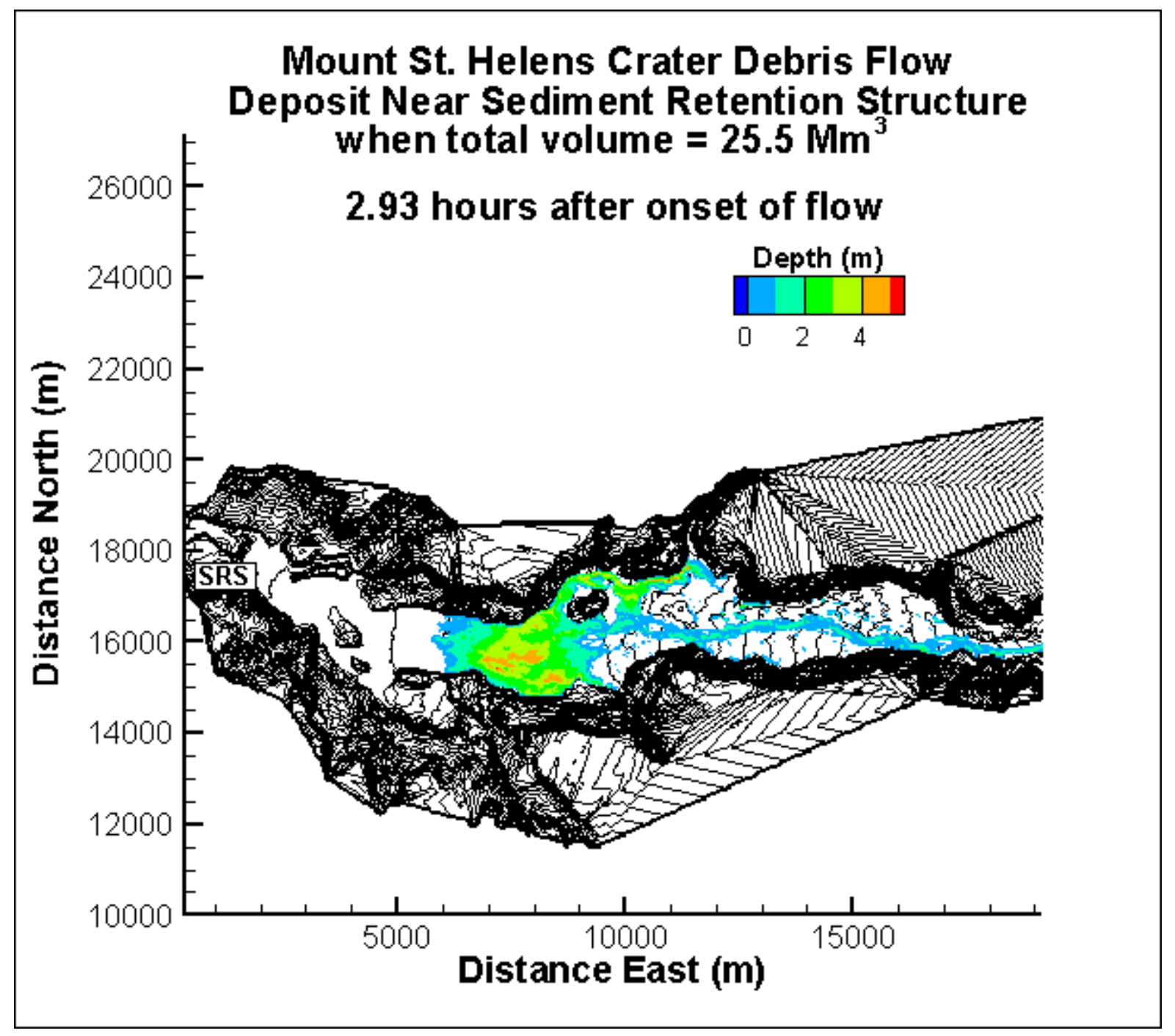

Figure 15. Deposit created by a debris flow originating in the crater of Mount St. Helens nearly 3 hours after its release. Debris is still moving in the channel feeding the deposit, but most of the material has come to rest. Note the levees and portions of the flow remaining stranded. Debris flows from the crater reduce the storage of the Sediment Retention Structure far more than large floods, as all the sediment volume is deposited in low areas behind the dam. See text for explanation of UTM datum. 